TITLE:

\title{
First Finding of the Amphipod Centromedon pumilus (Lilljeborg, 1865) in the Sea of Japan and Description of the Species
}

\section{$\operatorname{AUTHOR}(\mathrm{S})$ :}

Budnikova, Luydmila L.

\section{CITATION:}

Budnikova, Luydmila L.. First Finding of the Amphipod Centromedon pumilus (Lilljeborg, 1865) in the Sea of Japan and Description of the Species. PUBLICATIONS OF THE SETO MARINE BIOLOGICAL LABORATORY 1994, 36(4): 283-291

\section{ISSUE DATE:}

1994-11-15

URL:

http://hdl.handle.net/2433/176232

\section{RIGHT:}




\title{
First Finding of the Amphipod Centromedon pumilus (Lilljeborg, 1865) in the Sea of Japan and Description of the Species
}

\author{
LuYdMILA L. Budnikova \\ Laboratory of Shelf Communities, Institute of Marine Biology, \\ Far East Branch, Russian Academy of Sciences, \\ Vladivostok 690041, Russia
}

With Text-figures 1-5

\begin{abstract}
Centromedon pumilus (Lilljeborg, 1865) described originally from the Norwegian coast and redescribed from the North Atlantic, is described here, based on one female specimen found in the Sea of Japan.

Key words : Amphipoda, Centromedon pumilus, Sea of Japan
\end{abstract}

\section{Introduction}

Centromedon pumilus (Lilljeborg, 1865) has been known as a sub-Arctic shallow-water species inhabiting the North Atlantic and spreading as far east as the Carskoye Sea, inclusively. Oleröd(1980) defined more precisely the distribution of this species and redescribed it, reporting the occurrence of this species in the Bering Sea. The data obtained by the Zoological Institute, Russian Academy of Sciences, at Sankt-Peterburg also indicate its occurrence in the Bering Sea, being identified by Dr. E.F. Gurjanova. Further, V.A. Kudrjashov (1968) recorded the species from the north-eastern part of the Okhotsk Sea.

The present specimen, collected from the northern part of the Japan Sea, represents the first record of this species in the Japan Sea, and it is described in this paper for comparison.

\section{Centromedon pumilus (Lilljeborg, 1865)}

(Figs. 1-5)

\begin{abstract}
Anonyx pumilus Lilljeborg, 1865, Nov. Acta Soc. Sci. Upsala, 3, 3(6), 1: 26-27, Pl. 4, figs. 35-41.
Centromedon pumilus Sars, G.O., 1891, Crust. Norw., 1: 100-101, p1. 34, fig. 2; Stappers, 1911; Schneider, 1926; Stephensen, 1935; Gurjanova, 1951; Oldevig, 1959; Kudrjashov, 1968; Oleröd, 1980.

Material examined: One female (collection of the Institute of Marine Biology, Vladivostok, N 0/4-91), off Mys Chikhacheva Cape, Sakhalin I., depth $50 \mathrm{~m}$, silty sand, Station $325,47^{\circ} 27^{\prime} \mathrm{N}$, $141^{\circ} 57^{\prime} \mathbf{E}$, Sample 843, August 1977, V. Gulbin coll.
\end{abstract}

Description.

Publ. Seto Mar. Biol. Lab., 36(4): 283-291, 1994.

(Article 22) 
Body $7.2 \mathrm{~mm}$ long, flattened laterally. Pleonite 3 and urosomite 1 with a small rounded dorsal keel. Lateral cephalic lobes produced to form long projections. Eyeless.

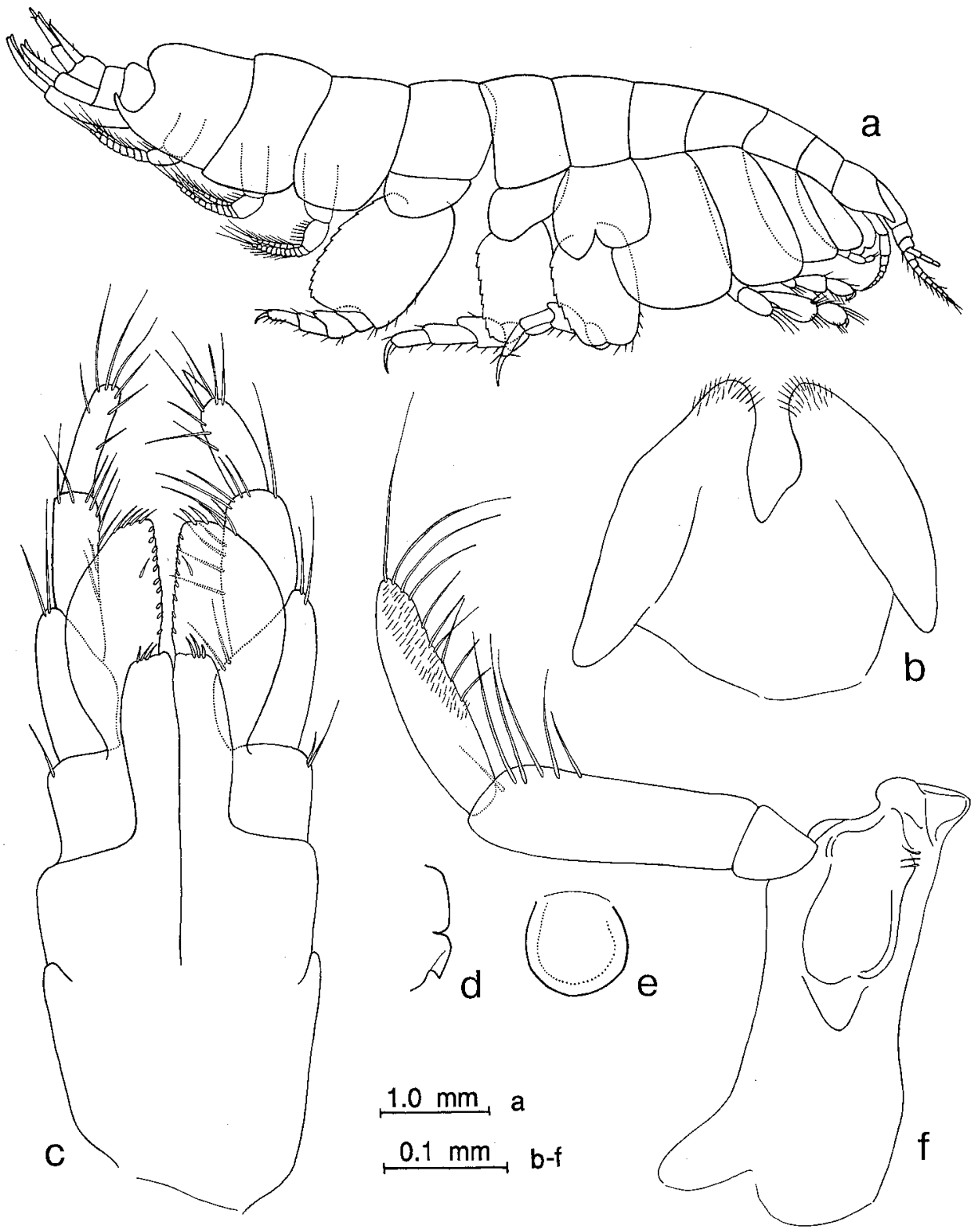

Fig. 1. Ceniromedon pumilus (Lilljeborg, 1865), female, $7.2 \mathrm{~mm}$ : a - habitus; b - labium; c - maxilliped; d - epistome and labrum, lateral view; e - labrum; f - mandible. 


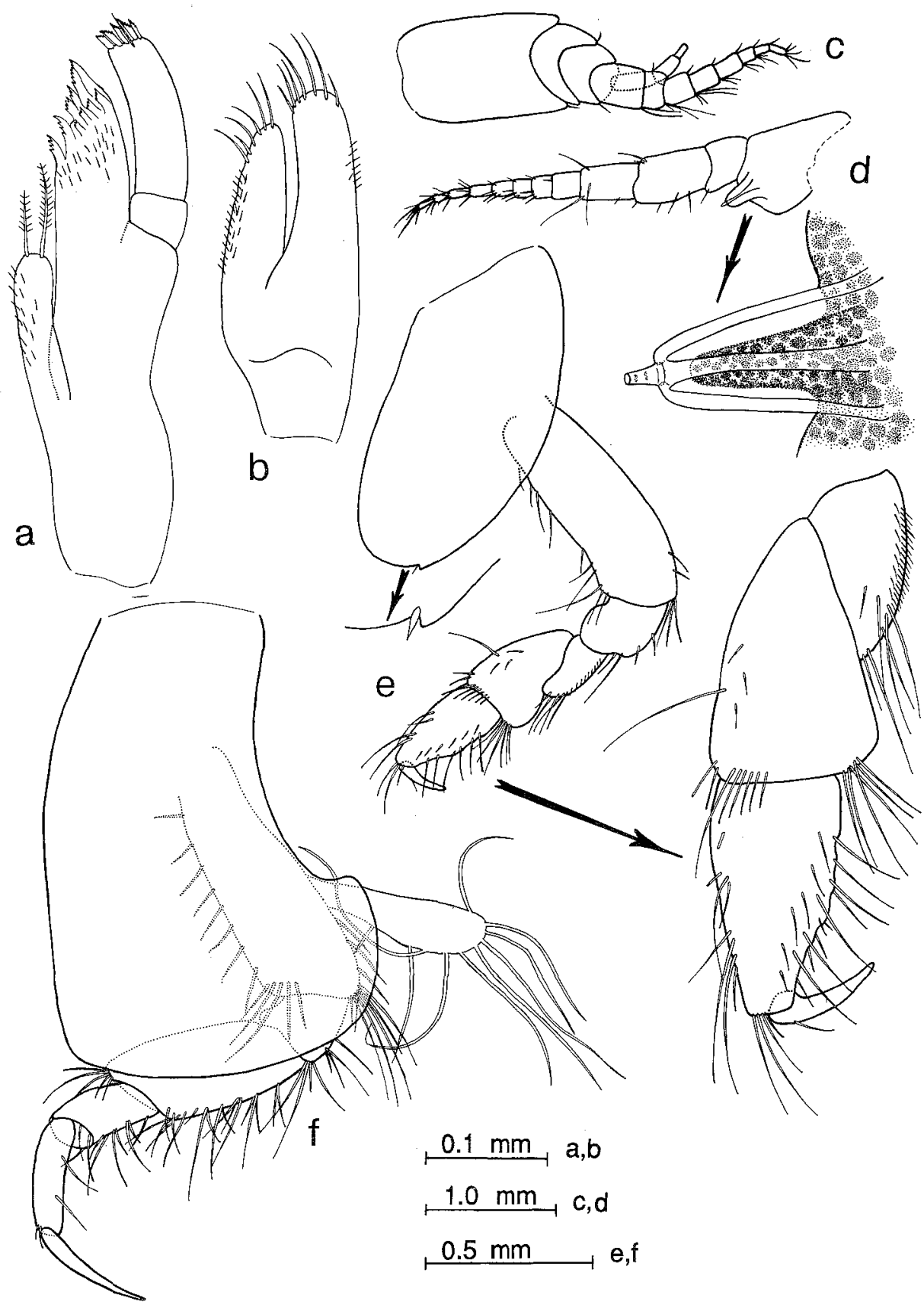

Fig. 2. Centromedon pumilus (Lilljeborg, 1865), female, $7.2 \mathrm{~mm}$ : a - maxilla 1; b - maxilla 2; c - antenna 1; d - antenna 2; e - gnathopod 1; f - pereopod 4. 
Antennae 1 and 2 nearly equal in length, short, less than $1 / 5$ of body length. First peduncular article of antenna 1 without keel, 2 times longer than articles 2 and 3 combined; articles 2 and 3 equal in length; flagellum 8-articulate, articles setose, dorsal setae short, ventral setae long; accessory flagellum 3-articulate. Peduncle of antenna 2 twice longer than flagellum, bearing a few setae; gland cone high; last article of peduncle half as long as penultimate article; flagellum 7 -articulate, setose.

Epistome not protruding forward beyond limit of upper lip. Labrum with rounded anterior margin. Labium without inner lobe; apex of outer lobe pilous.

Mandible with straight incisor, a spine row of 3 spines; molar conical, devoid of triturative area; palp 3-articulate, attached above and anteriorly to molar, with long setae on distal and penultimate articles.

Maxilla 1 with 2-articulate palp bearing 5 apical pectinate spines and 1 thin seta; inner lobe bearing 2 long plumose setae and thin hairs along inner margin; outer lobe armed with 10 sharp pectinate spines arranged in 2 rows, with thin facial hairs.

Maxilla 2 bearing long setae on apex of each lobe and thin hairs marginally.

Maxilliped. Inner lobe nearly half as long as outer lobe, with transverse apex bearing 3 short setae each. Outer lobe broad, not reaching distal edge of article 2 of palp; left lobe bearing 1 lateral seta at the base and 10 very short spinules along inner margin; right lobe with 2 lateral setae at the base and 8 very short spinules along inner margin; each lobe with 4 apical and 1 dorsal setae. Palp 4-articulate; distal article slightly shorter than half the length of penultimate article, devoid of apical setae; other articles with long distal setae, articles 2 and 3 with additional setae along inner margin. The specimen studied has evidently defective left palp; it lacks article 4.

Coxal plates increasing in size from 1 to 4 , coxal plates $1-3$ possessing 1 small denticle on posterior margin. Coxae 1 and 3 with parallel margins. Coxa 4 with posterodistal margin notched, its distal part twice broader than proximal part, anterior and posterior margins slightly convex. Coxal plate 5 nearly square, 2-lobed, posterior part narrower and somewhat longer than anterior part. Coxal plate 6 smaller than 5, also 2-lobed, posterior lobe considerably longer than anterior lobe. Coxal plate 7 small, rounded.

Gill vesicles elongated, attached to coxae 2-6. Oostegites present on coxae 2-5.

Gnathopod 1 shorter than gnathopod 2. Basis with parallel margins, with long setae arranged along its anterior margin. Articles 2-5 with bundles of long setae located on posterodistal corners; posterior margin of article 4 trimmed with thin hairs. Article 5 cup-shaped, as long as article 6, with 1 long and several short setae on anterior margin. Article 6 tapering distally, with indistinctly demarcated palmar margin without locking spines, armed with a bundle of long distal setae, 1 row of long setae and short setae on posterior margin, with several long setae on anterior margin. Dactyl equal in length to palmar margin with proximal seta on anterior margin.

Gnathopod 2 with basis slightly dilated distally and bearing setae on anterior 


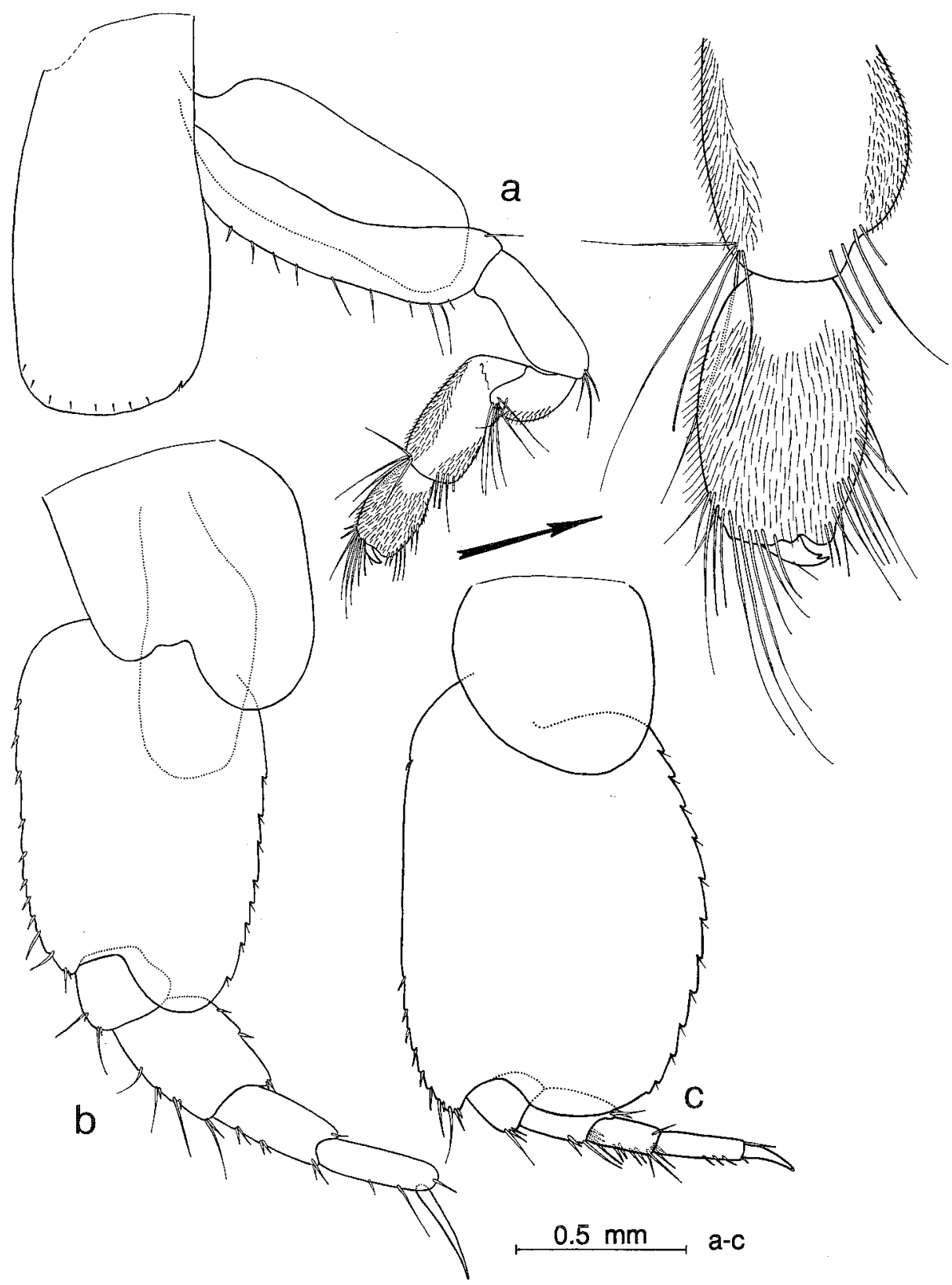

Fig. 3. Centromedon pumilus (Lilljeborg, 1865), female, $7.2 \mathrm{~mm}$ : a - gnathopod 2; b - pereopod 6 ; c - pereopod 7. 


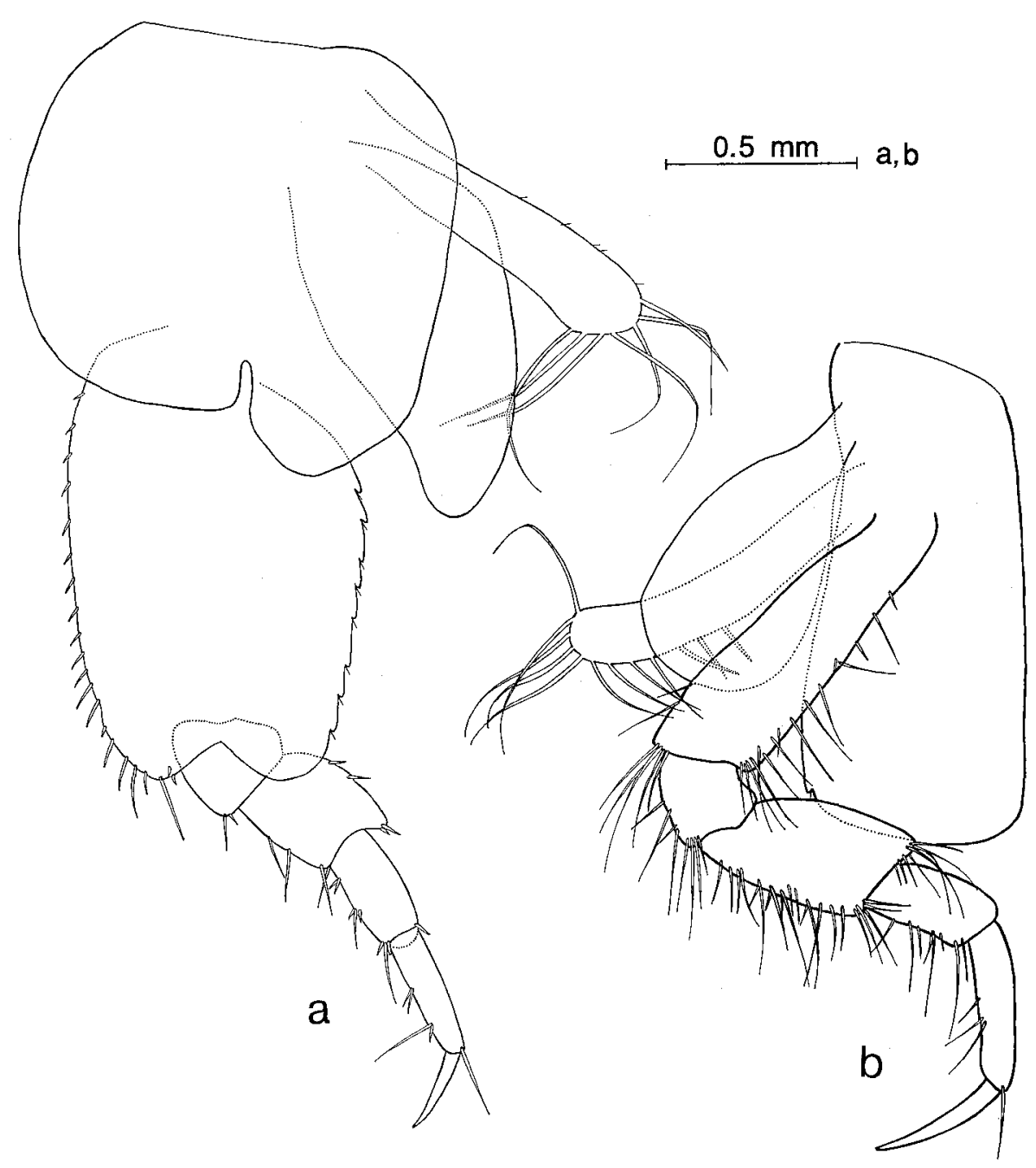

Fig. 4. Centromedon pumilus (Lilljeborg, 1865), female, $7.2 \mathrm{~mm}$ : a - pereopod 5; b - pereopod 3 .

margin. Article 3 half as long as article 2, as long as article 5, armed with 3 distal setae. Article 4 longer than $1 / 2$ length of article 3, bearing a bundle of long distal setae and thin hairs along posterior margin. Articles 5 and 6 with long distal setae, trimmed with thin hairs arranged along anterior and posterior margins on article 5 and almost all over surface of article 6 . Article 6 ovate, palmar margin short and straight. Dactyl with bifurcate end and 1 seta on outer margin.

Pereopods 3 and 4 similar in structure; their basal articles long, slightly delated distally, with long setae along anterior margin, groups of distal setae and a few setae in distal quarter of posterior margin; articles 3 to 6 bearing groups of long and short setae on posterior margins; article 4 furnished with a bundle of setae on anterodistal 
corners; dactyls equal in length and form. Article 4 of pereopod 3 shorter and broader, article 6 longer than corresponding articles of pereopod 4 .

Pereopods 5 and 6 nearly equal in length; pereopod 7 considerably shorter; basis
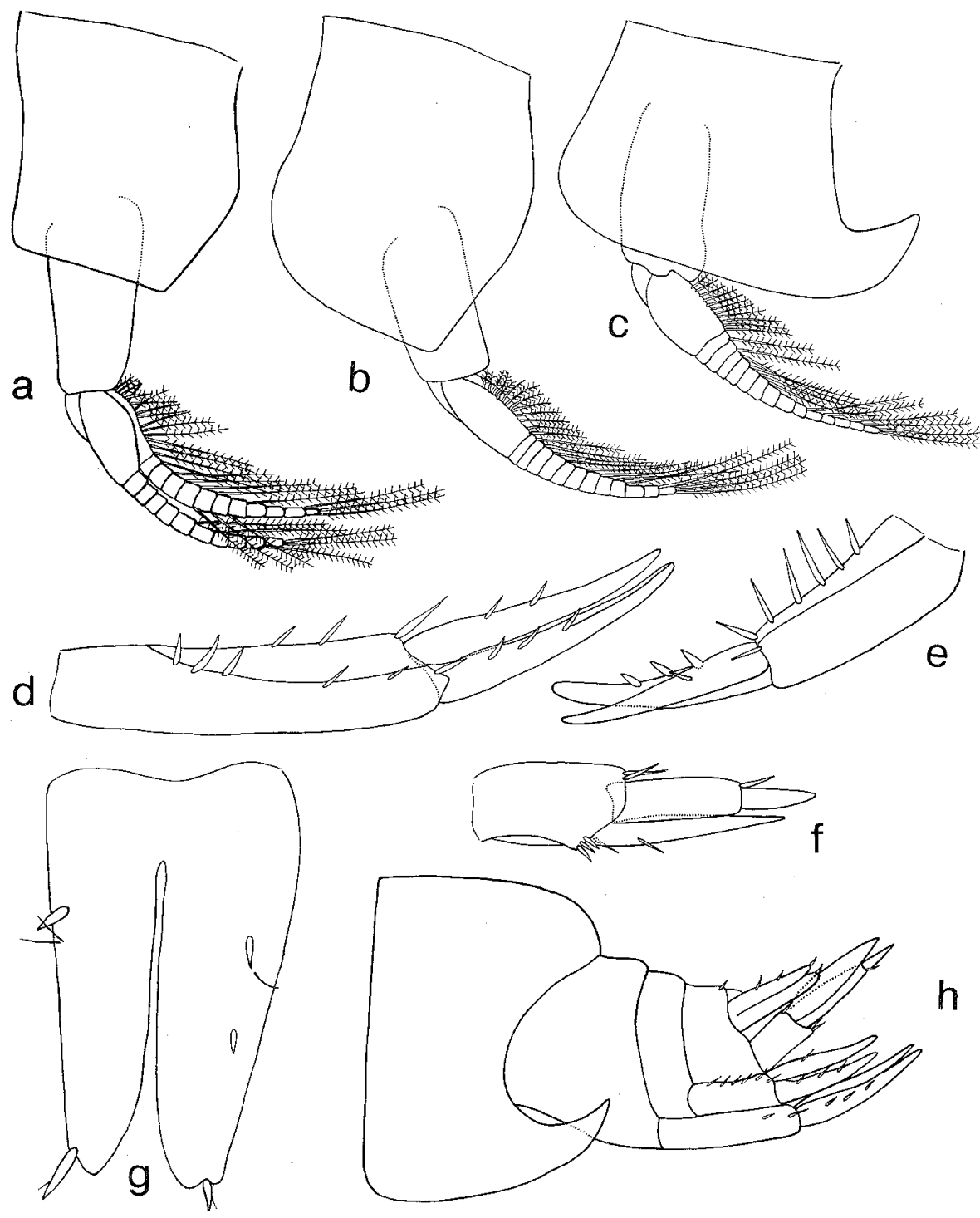

$0.1 \mathrm{~mm}, a, b, c \stackrel{0.2 \mathrm{~mm}}{\longmapsto} d, e, f \stackrel{0.2 \mathrm{~mm}}{\longmapsto} \stackrel{0.5 \mathrm{~mm}}{\longmapsto} \mathrm{h}$

Fig. 5. Centromedon pumilus (Lilljeborg, 1865), femalc, $7.2 \mathrm{~mm}$ : a,b,c - epimara and pleopods $1,2,3$; d,e,f - uropods 1,2,3; $\mathrm{g}$ - telson; $\mathrm{h}$ - last plcomer and urosome. 
with serrate posterior margin and spines on anterior margin in pereopods 5-7. Basis of pereopod 5 slightly tapering distally, posterodistal corner produced to form small lobe; article 3 short, with a pair of spines on anterodistal corner; article 4 dilated, with distal and lateral spines and setae on anterior and posterior margins; articles 5 and 6 devoid of armament on posterior margin, article 5 equal in length to article 4 and shorter than article 6 ; dactyl narrow, longer than $1 / 2$ length of article 6 . Basis of pereopod 6 with practically parallel anterior and posterior margins, posterodistal corner protruded to form rounded lobe; other articles similar to corresponding articles of pereopod 5, but articles 4 and 7 longer than those of pereopod 5. Pereopod 7 with longest and broadest basis with convex posterior margin and broad posterodistal lobe, spines arranged on distal third of anterior margin of basis; total length of all following articles shorter than basis, their form and armament almost the same as in pereopods 5-6, but sizes considerably smaller.

Epimeron 1 elongated; anterior margin straight, slightly concave in the middle, ventral margin straight; posterior margin oblique. Epimeron 2 with smoothly rounded ventral part of anterior margin, straight ventral margin and convex posterior margin. Epimeron 3 dilated ventrally, posterodistal corner protruded to form long and sharp process slightly recurved dorsally. Pleopods 1-3 similar in structure, equal in length, with long plumose setae on both rami.

Uropods 1-3 diminishing in size posteriorly. Tips of rami of uropod 1 at the level of tips of rami of uropod 3, tips of rami of uropod 2 reaching only about $3 / 4$ of the length of rami of uropod 1. Peduncle of uropod 1 rounded on ventral side, concave with two ridges on dorsal side, edges of ridges and distal part armed with stout spines; both rami equal in length, as long as $3 / 4$ of peduncle, outer ramus with 3 spines, inner ramus with 2 spines. Peduncle of uropod 2 half as long as peduncle of uropod 1, similar to that in form, with 2 distal spines and 5 stout spines on outer ridge; both rami equal in length and as long as peduncle, outer ramus with 3 spines, inner ramus with 1 spine. Uropod 3 slightly shorter than peduncle of uropod 1; peduncle shorter than rami, slightly dilated distally, with 2 bundles of distal spines; outer ramus 2-articulate, article 1 with 1 distal spine, article 2 longer than half length of article 1 , with no armament; inner ramus reaching middle of article 2 of outer ramus, proximal half with 1 setule.

Telson long, narrow, split nearly to the base; each lobe with 1 apical apine, apical spine with 1 very thin hair; left lobe with 1 dorsal spine and 1 pair of hairs; right lobe with 1 pair of dorsal spines and 1 hair.

Remarks.

The present specimen differs from the original description (Lilljeborg, 1865) and the redescription (Oleröd, 1980) in several characters, which are not significant for specific differences: the palmar margin of gnathopod 1 without locking spines, the apices of telson lobes with one spine only. It differs from the latter specimens from Spitzbergen (Oleröd, 1980) in the armature of inner lobes of maxilliped and in the shape of coxal plate 5 . 


\section{Acknowledgements}

My cordial thanks go to Dr. V.A. Kudrjashov for his helpful advice and critical reading of the manuscript. The work was partly supported by the grant from the International Science Foundation.

\section{References}

Gurjanova, E.F. 1951. Gammaridean Amphipoda of the seas of the USSR and adjacent waters. In: E.N. Pavlovsky (cd.), Opredeliteli po faune SSSR (Identification Keys for Fauna of the USSR), USSR Academy of Sciences, Moscow, Leningrad, 41, 1029 pp., 705 figs. (in Russian)

Kudrjaschov, V.A. 1968. Composition and patterns of distribution of amphipod crustacean fauna of north-eastern part of the Sea of Okhotsk. Uchenye zapiski Dal'nevostochnogo gosudarstvennogo universiteta (Proceedings of the Far East State University), 15(2): 86-116. (in Russian)

Lilljeborg, W. 1865. On the Lysianassa magellanica H. Milne-Edwards and on the Crustacea of the suborder Amphipoda and subfamily Lysianassina found on the coast of Sweden and Norway. Soc. Sci. Upsala Nov. Acta, 3, 6(1): 1-38, pls. 1-5.

Oldevig, H. 1959. Arctic, subarctic and Scandinavian amphipods in the collections of the Swedish Natural History Museum in Stockholm. K. Vet. O. Vitterh. Handl., F.6, Ser. B, 8(2): 1-132.

Oleröd, R. 1980. A taxonomic study of the Lysianassid Genus Centromedon G.O. Sars (Crustacea, Amphipoda). Zool. Scripta, 9: 35-52, 124 figs.

Sars, G.O. 1891. Amphipoda. An Account of the Crustacea of Norway with Short Descriptions and Figures of All the Species. Volume 1. 711 pp., 240 Pls.

Schneider, Y.S. 1926. Tromsosundets amphipoder, isopoder og cumaceer. Tromsø Mus. Aarsh., 47(8): $1-173$.

Stappers, L. 1911. Crustaces Malacostrances. Duc d'Orleans Campagne Arctique de 1907. Bruselles. Tome 7. iv $+152+$ xii + xii pp., 7 pls., 2 charts.

Stephensen, K. 1935. The Amphipoda of North Norway and Spizbergen with adjacent waters, 1-4. Tromsø Mus. Skrift., 3(4): 363-526. 